\title{
Social movement theory and the Italian radical community archives: A question of valence?
}

Mark Howard
Teaching and Research associate, School of Philosophical, historical and International Studies, Monash University, Australia

Corresponding Author.

mark.howard@monash.edu

The theory and practice of the radical community, and a capacity for self-organisation, demonstrates the ability to control the symbols and language of society, to define new conventions of meaning, and to offer alternative reasons and explanations for action. However, the predominant sociological account of Italian social movements of the 1960s and 1970s censures potentially relevant discursive practices of the radical community. This is evidenced by the lack of diversity amongst the epistemic sources of Anglo American Social Movement Theory (SMT). The assumptions in play in disciplinary thought disqualify the practice and theory of radical social movements as a credible mode of analysis of the social and political condition. Ultimately, this discounts the radical subject as knowledge producer. By reflecting on my personal experience of conducting doctoral research at three key community archives in Italy I contemplate an alternative approach, which considers the valence of these radical communities as essentially epistemological and not simply 'political', or social.

Howard, M. (2019). Social movement theory and the Italian radical community archives: A question of valence?. The Journal of Community Informatics, 15, 19-XX.

Date submitted: 2018-03-31. Date accepted: 2018-10-31.

Copyright (C), 2019 (the author as stated). Licensed under the Creative Commons AttributionNonCommercial-ShareAlike 2.5. Available at: www.ci-journal.net/index.php/ciej/article/view/1414 


\section{Introduction}

I travelled to Italy in 2011 to conduct doctoral research at three key radical community archives: The Archives of Primo Moroni (APM) hosted by the Cox 18 social center in Milan; the Workers' Archives of Augusto Finzi (AAF) managed by the Marghera Public Library; and The Centre of Documentation in Pistoia (CDP). Prior to these archival visits, my inquiry into the nexus of the radical community and politics in Italy for the period 1968-78 had primarily leveraged the theory and epistemic systems of AngloAmerican Social Movement Theory (SMT). Consequently, the latter informed my habits of attention, with a modernist vision of the intersection of the political institution and social conflict guiding my choice of research subjects and materials. I deferred to the epistemic evaluations of leading figures in this field, such as Donatella della Porta and Sidney Tarrow, whose combined vision of a contemporary "movement society" describes a strategy-oriented radical community whose activism is centered on political strategy. ${ }^{1}$

One afternoon, after finishing my research at the APM, I took time to thumb through some counter-cultural magazines in the Cox 18 bookshop. During this time the musings of Jacques Rancière (1989) in The Nights of Labour came to mind: "is it possible that the quest for the true word compels us to shush so many people? What exactly is the meaning of this evasion (...)?" That moment would alter the trajectory of my research. Subsequently, my interest in the disciplinary approach of sociology to the discursive work of the radical political subject and the holdings of radical community archives has been informed by my personal experiences of conducting research at the aforementioned archives and my ensuing intellectual engagement with Italian radical theory. This is my attempt to redress the disciplinary prejudice I became aware of while encountering the social documents of the Italian radical community.

I argue that the predominant sociological study of Italian social movements of the 1960s and 1970s involves a willful exclusion of potentially relevant theoretical practices such as those of radical political subject in the analysis of the nexus of the radical community and politics. This censure is evidenced by the lack of diversity amongst the sources of justification, knowledge, and evidence - epistemic sources - of SMT. Vitally, I assert, the choice of materials and subjects (habits of attention) is founded on presumptions of testimonial credibility assigned on the basis of the sociological identity that SMT affords the radical political subject. Coupled with academic positivism and a reductionist approach to the epistemology of testimony, disciplinary thought treats the discursive work of radical social movements (RSMs) (speech acts and written communication that develop and articulate ideas of the radical actor) as the material of the theorist, an objectification that abstracts the social documents from their context and prejudices the response of SMT to the archival work of the Italian radical community.

1 See, for example: Sidney Tarrow, Democracy and Disorder: Protest and Politics in Italy, 1965-1975, New York, Oxford University Press, 1989. 


\section{The radical community, discursive work and epistemic agency}

When we put ourselves in contact with a mass movement, in reality we are opening a relationship with organisms which are already politically mature. So this completely changes the vision which makes the political elite an active subject and the mass movement a passive subject: the political elite, a kind of stratum endowed with knowledge and, instead, the mass movement, a stratum endowed only with wishes, with desires, with tensions and so on. (Bologna 1995)

Before my archival visits in Italy in 2011, I had drawn my research materials almost exclusively from the SMT store of documents. Vitally, the SMT habit of attention is guided by a modernist vision of a political system progressively improved by the presence of social conflict.2 Within this image of the contemporary "movement society" the important activity of the radical community is limited to political strategy and social interaction. Consequently, I argue, the knowledge work of the Italian radical subject is mis/underrepresented amongst the epistemic sources that SMT relies on to navigate their field of research. Having initially shared these sources, I was liable to think that the important discursive work of RSMs was exhausted within identitarian, rationalist, and structuralist aspects of social action. Further, I believed that the political concepts and arguments of the Italian radical community 1968-78 were adequately represented within, first the 'official transcripts' of the Italian State informants (the pentiti); second the journals of key social movement organisations such as Potere Operaio (PO/ Workers' Power) and; third the theoretico-political interventions of historic Marxism and neo-Leninism.

Contra my experience with the epistemic sources of SMT, the expansive collection of social documents - the products of the radical subject's discursive work - at CDP, AAF and APM ranged across newspapers, journals, counter-sociology periodicals, leaflets, magazines, anthologies, historiographies, interview transcripts, life-histories and more. The CDP, unique amongst these archives was established as a "place of critical research" in the $1960 \mathrm{~s}$, does not represent a specific political tendency. ${ }^{3}$ In contrast AAF, as D'Agostino (2013) relays, presents local histories and gathers documents that aim to preserve social and political memory specific to the radical community of the Veneto. Finally, the APM is hosted by a Milanese social centre, and continues to offer a place of resistance and to fulfil a political purpose; however, the diversity of materials addresses the accusation of exclusive habits of attention. Certainly, the APM promotes militant publications of the far left, yet the depth and breadth of its holdings go some way toward achieving its stated aim to "socialise knowledge without establishing power". ${ }^{4}$ This, I observe, is an attempt to redress the

2 This is patent, for example, in the research of avowed consensus theorist Sidney Tarrow (1989).

$3 \mathrm{http}: / /$ www.centrodocpistoia.it/index.php?menu=sub2item2\&page=storia

4 http://www.inventati.org/apm/index.php?step=introduzione 
epistemic harm experienced by the radical community, a result, as I explain below, of the social identity and location afforded them by traditional knowledges.

After exploring these archives I left Italy appreciating the radical community's discursive work as an authoritative and credible body of work analysing the nexus of politics and the radical subject. Their social documents demonstrate rational authority: they generate expertise, offer new theoretical insights, produce arguments and questions, and as Casas-Cortes (2008) and her co-authors spotlight, are 'acts of knowing' potentially equivalent to those of social theorists. While the Italian radical community archives may be, in certain instances, integral to the agency of the radical community, foregrounding their values (Wright, forthcoming), the social documents they hold are not limited to the resources of political practice. In two important aspects, the discursive practices of the radical community are, I assert, in line with the standards of knowledge creation recognised as legitimate by social epistemologists such as Fuller (2012). In particular, the radical communities involved in the production of the social documents exhibit the features of an epistemic community: they judge the credibility of testimony based on shared schemas of epistemic evaluation; they demonstrate the capacity for epistemic agency - the ability to "make sense of one's experiences" (Dotson 2014) and; their documents affect knowledge outside of the context of creation. How then are we to explain the censure of the radical community, and the absence of its mass communications within the prevailing Anglo-American theory of the nexus of politics and the radical community?

\section{Knowledge practices}

The theory and practice of the radical community, their documents, discursive works, and a capacity for self-organisation, demonstrates their ability to control the symbols and language of society, to define new conventions of meaning, and to offer alternative reasons and explanations for action. Key, as I have argued elsewhere (Howard, 2017), is that RSMs exist marginal to the political community, acting outside the established standards of behaviour. This has the effect of disrupting social order and the discourses that have that order as their object. By conceptualising the nexus of politics and the radical community in this way, we imagine a collective actor that generates both practical (real life/subjective) and theoretical (discourse/objective) discontinuities which are exemplary of radical activity. Their self-aware practices of immediacy achieve real life outcomes by directly dealing with the impediments present in the environment. The correlate effect of the observation of these practices in the discourse on politics, is an undermining of existing schemas of thought, driving theoretical renewal. ${ }^{5}$ A case in point, amongst the self-activity of the contemporary Italian movement sector, is the early risers of the workers movement in the late 1950s and early 1960s who intended to

5 My conceptualising of the radical community here is indebted to Deranty and Ross' introduction in (Deranty and Ross 2012), and Rancière's elaboration of revolutionary practice in (Rancière 1991). 
"change the relation of the factory workers to the political and industrial systems (Howard, 2017)."

As Castellano (1996) and his co-authors note, the early risers were self-organised and took charge of their work environment through direct action. This worker was fundamentally different to that elaborated within the traditional or classical theories of class antagonism (Cuninghame 2002), and created redundancies and gaps in established political thought, notably the Marxist thought of the Italian Communist Party. Accompanying the self-activity of the workers, responding to theoretical discontinuity, was an emerging and novel theoretical expression of the relation of the worker to the state and capital. This theoretical renewal resulted in the intellectual circle that crystallised around the seminal journal Quaderni Rossi and were drawn into the social conflict. As Bologna (1995) observes amongst his historiographic notes, the coming together of the intellectual stratum and the mass movement revealed the latter was already endowed with knowledge and the capacity for self-activity.

Radical communities, when manifest as social movements, are widely recognised to generate knowledge of the conditions underlying social and political conflicts (Diani and Eyerman 1992). Invariably, however, the Anglo-American study of the radical actor grants certain intellectual circles a monopoly over the comprehension of the 'object' of study, limiting explication to the confines of traditional expert knowledges. The outstanding question is why does a discipline, which Zwerman, Steinhoff, and della Porta (2000) assure us is attentive to the 'vicissitudes' of the entire social movement milieu, collapse the Italian social movement sector into the political process, flattening the context of the radical community and conflating its innovation and creativity with strategic reason and political rationalism? The beginning of an answer, I suggest, is available in the confluence of social epistemology and community informatics, and their conjuncture with the contemporary methodology of SMT.

Researchers must continually discriminate between competing sources of evidence, knowledge and theoretical justification, argument and counter-argument, selecting what we believe to be credible informants and reliable testimony. Typically, as Goldman (2011) explains, we utilise methods of evaluation that reflect the social processes, institutions and procedures, and interpersonal influences common to our disciplinary milieu. Cumulatively, these influences form 'epistemic systems' that aim to promote truth and, as Goldman continues, embedded within these systems are schemas of epistemic evaluation that "affect the epistemic outcomes of its members." Schemes of epistemic evaluation are employed to validate, for example, judgements of expertise. Such validation utilises properties of the hearer and informant (such as social location) to exclude or promote potential testimony (Goldman 2001; 2011). While conceding that knowledge practices are not egalitarian, epistemology attempts to avoid unfair discrimination and partisan habits of attention. ${ }^{6}$ Therefore, epistemology is concerned

$6 \quad$ On this topic, refer to Fricker (2011) and Dotson (2014) 
with, among other things, choices of epistemic sources. These choices are ubiquitous in research and documentation environments, and are affected by variables such as doctrinal attachments, methodological and theoretical commitments, institutional and cultural practices, and the social and political context of investigation. As a result, the privileging or trivialising of social subjects, research materials, and memory is a common concern of applied social epistemology and community informatics. Their concerns share territory that covers the objectifying of testimony and its abstraction from community contexts; the place of 'official records/memory' in research strategies and knowledge practices; and the role of the radical community in the presentation of social documents in archival situations. ${ }^{7}$

Of concern to politically-minded social epistemologists, such as Miranda Fricker (2011), is that social identity and location can affect the rational or cognitive authority afforded to certain informants. These decisions are often founded upon "societal norms of credibility" that reflect existing social hierarchies and power relations (e.g. man/ woman), and involve the legitimising of certain 'rhetorical spaces' that generate "presumptions of credibility." Code (2011) explains that these spaces, areas of discourse, limit and structure what can be uttered and trusted as testimony and grant authority to certain speakers and interpreters, dependent on their positioning within the space. The result is considered unfair epistemic discrimination (Fricker 2011), which, key to our concerns, can take the form of either exclusion from, or promotion within, a community of knowers. Such 'political standards' of discrimination, Dotson explains, is the unwarranted hindrance to epistemic agency, constraining the "ability to utilise persuasively shared epistemic resources (...) in order to participate in knowledge production." The outcomes of unfair discrimination include impediment to effective and accurate communication and recognition of the capacity to "make sense of one's experiences" (Dotson 2014). As is discussed below, the Italian radical community suffers both forms of harm at the hands of disciplinary thought and interventionist intellectuals.

In the Italian situation, disciplinary thought sweeps aside localised actions and discourses of various subgroups within the social movement environment, and treats the radical community as the material of the theorist. The rhetorical spaces, schemes of evaluation and epistemic sources of SMT have the effect of disqualifying the practice and theory of the radical actor as a credible mode of analysis of the social and political condition. Crucially, I contend, SMT wilfully excludes relevant theoretical practices in the modelling of RSMs based on 'political standards' of epistemic evaluation and partisan habits of attention. As a discipline, it limits the valence of radical thought to that of political strategy, or social interaction, and fails to acknowledge the potential for radical action to co-exist with epistemological work. SMT has an intrinsic aversion to the intellectual labour of the radical community, and a distrust of the social documents

7 Similar themes are discussed from the perspective of community informatics in Stillman \& Johanson 2009. 
held in radical community archives, evidenced by its sources. However, as I have argued elsewhere (Howard, 2017), to understand the knowledge practices of the radical community we must recognise their valence, which is essentially epistemological and not simply political, or social. 8 This is to claim that the radical subject is at least potentially a credible informant, and that we can learn from their theory and practice. The radical community, through their actions, verify a common capacity, as Rancière highlights, for the invention and demonstration of political concepts, arguments, objects, and the like (Baronian, Rosello et al. 2008).

\section{The valence of the radical community}

During the first half of the twentieth century the study of social movements marginalised movement participants based upon the image of the activist as defective and collective behaviour as outside of reason (McPhail and Tucker 2003). However, during a period of social foment in the 1960s, typified by the rise of left-libertarian movements, the dividing line between theorist and activist, intellectual and movement, was often blurred. In Italy, innovative forms of practice and theory, alongside collective violence, typified a movement sector embodied by a class of movements that railed against the standard place of the radical community in politics. The redundancies and breaks this social movement sector created in established thought engaged the intellectual in a process of theoretical rejuvenation. Against this background, SMT began to reconstruct its explanatory framework, disenchanted with aspects of the disciplines contemporary inheritance (Eyerman 1989). At the same time, a similar process was occurring amongst the radical community and a counter-sociology movement in Italy.

As the polarisation of the political climate faded, theoretical renewal translated most prominently into the ascendance of the rational choice frameworks of SMT, the Autonomist Marxism of Italian radical thought, and the post-Marxism of European social movement theory. SMT also employed the 'classical agenda' of research in an effort to 'civilise', 'politicise', or 'organise' the radical subject by repatriating them to institutional politics. This had the effect of promoting the political valence of the radical community, and, as McAdam (2001) and his collaborators state, the overarching intent was to repopulate the territory of modern politics with a strategic and reasonable radical subject, specifically, one identifiable and explicable within a framework of political rationalism. Guided by this agenda, after a period of theoretical upheaval, the discipline returned to a more traditional subject/object split, with the sociologists adopting a 'disengaged' and 'neutral' position (Diani and Eyerman 1992). The theoretical implications of this approach, as discussed by Casas-Cortés, Osterweil, and Powell (2008), include, first, objectifying the radical community, which discounts them as

8 Alberto Toscano (2010) discusses the importance of considering the valence of radical communities in his work on fanaticism. 
knowledge producers, and second, a distrust for non-traditional sources of expertise and the unique insights available amongst localised and particularised practices.

In this context, a further crucial factor shaping the re-birth of the Anglo-American study of social movements, and its subsequent interaction with radical thought, was the summary dismissal of Marxist social theory as a credible epistemic source. The negative valence afforded Marxist thought is evident in the hostile post-Marxist approach of SMT, which attempts to purge the analysis of contemporary social movements of the knowledge and praxis of Marxist radical subjects. Crucially, this effort relies on a caricature of Marxism that firstly invokes a monolithic image of historical Marxism and then promotes neo-Leninism as representative of Marxist renewal in Italy. Carried forward by a superficial encounter with historicist Marxism and the aggressive brand of Marxism-Leninism associated with the Italian area of organised violence, SMT affords Italian radical thought diminished credibility in the rhetorical space of social movement study. Consequently, SMT avoids critically engaging with the Marxist renewal that occurred during the 1960s and 1970s. Significantly, the coarse classificatory net utilised to disbar Marxist thought from the status of interlocutor in the Italian situation overreaches, capturing the theory and practice of autonomous and self-organised collectives that circulate within a political territory typical to Marxist interventionism.

Effectively, SMT isolates Marxist thought and uses its caricature to quarantine the practice and theory of the radical community. The assumptions in play are used in a strategic fashion to disqualify certain agents and aggrandise others; however, their justification for epistemic discrimination is tenuous. First, Marxist theoretical renewal in Italy was driven, as Bologna identifies (Cuninghame and Bologna 1995), by an attempt to open a relationship with a radical community already 'endowed with knowledge' and a capacity of self-organisation. Its ambitions were not Leninist. In addition, Autonomous Marxism, a theoretical thread that ran throughout the Italian movement sector, was critical of orthodox and historicist Marxism and at its foundation it was a sociological investigation of the dynamics of social inequality. Accordingly, its status within the rhetorical space of sociology deserves careful consideration.

Second, the dismissal of the practice and theory of RSMs obscures the conjunction of the subjective and objective modes of radicalism, which involves an exchange between the movement and the intellectual, discrete, yet intimately entangled layers of the radical community. Consequently, thinking on the radical subject that proceeds largely unaffected by the specificity of a radically different theory and practice of politics risks, as Toscano has illuminated, reduces the thought and action of the radical community to an 'empty philosopheme' (Toscano 2009) — the emblematic statements and pronouncements of leaders and political elite. This reductive approach to the knowledge of the radical subject ignores its creativity and efforts to rethink politics itself.

The contemporary sociological study of the nexus of politics and the radical community proclaims, as McPhail and Tucker (2003) note to address the inequity of previous 
governance based theories of social movements that defended the existing social order and normalised the domination of the ruling classes (the men of reason/progress) over the lower classes (the crowd, the irrational and desirous masses). However, implicit to the persistence of theoretical positivism is the relation of knowledge and ignorance (those who know and those who do not know), that underpins knowledge hierarchies of unequal societies. The ontological division of society into the 'two humanities' of the active thinker and their passive medium, the masses (Rancière 2009), that reassured Marxist science of its guardianship of knowledge, also shores up the authority of disciplinary thought. This approach places the scientist and their account ahead of the participant and their expressions (Rancière 2004), creating an intellectual asymmetry that promotes the testimonial credibility of the former. As Kristen Ross spotlights, the 'new sociology' energised by the events of 1968 is accused by Rancière, among others, of "deriving its authority from the presumed (...) ignorance of its objects of study" (Ross 1991). Knowledge hierarchies, whether exploited by sociologists, movement leaders, and philosophers or similar, assign manual and intellectual labour to certain social identities based on schemes of epistemic evaluation. This creates a sense of entitlement and grants the strategic reason and political rationalism of certain intellectual circles a monopoly over the comprehension of the movement. 9

Rational authority, afforded on the basis of positioning in rhetorical spaces, occludes the capacity of those dominated in the existing social order to articulate and organise their experience. This hinders the epistemic agency of the radical community and undermines the credibility of their document work. The relevance of this assertion for SMT is evident in the thinking of della Porta (1992). She states that there is a "lack of scientific interest in the publication of "high fidelity" transcripts, without comment or interpretation". To extract the sociological content 'hidden' within the testimony, or to provide a scientific account of oral history, requires "the presence of research hypotheses and a good background knowledge." She continues that "even more important, sociological concepts and hypothesis are indispensable in selecting material and 'making sense' of it' della Porta (1992). The point is clear, della Porta believes that the discursive forms of the radical community require further explication, with sociological interpretation necessary to redress the 'vagaries', 'aesthetics' and 'distortions' present in their expressions and social documents (1992; 1995). Effectively, the credibility of the testimony of the radical actor is considered a function of the sociological employment of research 'devices' to counter "characteristic patterns of distortion." (della Porta 1992). The interpreter or social theorist, and not the speaker, is considered key.

della Porta's method of intervention, and a general aversion toward the radical community's analysis of their condition, is manifest in her privileging of select

9 Wright (2005) makes an important point when he asks whether we can accept the political elite as a necessary consequence of the radical community without assuming that they must form a "single political unit designed to monopolize the broader movement's 'strategic reason'?" 
materials and subjects. First are the 'official transcripts' of the pentiti: radical left activists who turned state informant and were central to the judicial case brought against the radical left. ${ }^{10}$ The Italian State approached political dissidence in the second part of the 1970s through a narrative of political illegality, reducing the radical community, as discussed by Moss (1997), to the social identities and locations of criminal, terrorist, marginal, or enemy. Such social categories disbarred the radical community from the intellectual labour associated with understanding the politics of radical social movements. However, the Italian State reintegrated repentant radical activists into the interpretive community as informants, part of the judicial interpretation that secured the meaning of high-cost activism (Moss 1997). The transcripts of pentiti interviews hold a central place in della Porta's account of the nexus of politics and the radical community, with the reliability of their testimony thought to be enhanced or rehabilitated by the judicial situation and subsequent sociological intervention.

Second, while not exclusive of left-wing media, della Porta's habits of attention (and Tarrow) further mimic those of the Italian State, relying on the theoretical interventions of historic Marxist and neo-Leninist intellectuals to explain the Italian radical political subject. This promotes social documents that represent the more 'aggressive' thread of 'high-risk' activism, associated with groups gathered around journals like Senza Tregua and Rosso. Ultimately, having shared numerous epistemic sources with the State's judiciary, della Porta cannot avoid becoming similarly enthralled with certain radical organisations and their leaders.

The reduction of the radical subject in Italy to the status of citizen solely in the eyes of the law afforded the judiciary interpretive privilege in the political and social conflict, providing authority to their fixing of the 'public' meaning of radicalism. ${ }^{11}$ The State's interpretive community identified the 'political dissident' by associating them with terrorism and a Leninist ideology. The prosecution claimed an intellectual 'MarxistLeninist' vanguard was leading the mass movement and had effectively quietened the voice of social movements outside the organisations of the worker. However, these 'censored' social movements themselves thought Leninism, while making lots of noise, had little to contribute in the face of the practices of the Movement of ' 77 . Ultimately, it was the State and the armed organisations that afforded the Leninists an important voice by verifying their place at the centre of the radical community, a situation that has its correlate in SMT, which privileges these 'experts' of political violence.

\section{The strategic radical subject}

SMT's effort to repatriate the radical subject to western democracy is facilitated by employing a theoretical framework that forms around an unchanging nucleus of instrumental reason and modern politics, limiting its account of the radical subject to an

$10 \quad$ See: Portelli, 1989.

$11 \quad$ Moss (1997) makes a similar point. 
exposition on how collective actors do things with strategic resources. This devalues the epistemic agency of the radical community, a community arguably irreducible to its political strategies and decisions. As Alain Touraine famously argued: "the concept of social movement is useful when it helps one to rediscover social actors (...) buried beneath either structural Marxist or rationalist theories of strategies and decisions" (Touraine 2008), both of which subordinate the radical community to programmatic and organised forms of politics. Such relegation is common to sociological accounts of social movements, where an organisational intent and explanatory purpose expropriates the radical subject from its knowledge of social struggle.

Central to SMT's explanatory framework is Frame Theory, which is accommodated to the extent that it complements a strategy-oriented modelling of the nexus of politics and the radical community. As McAdam (2004) discusses at length, this approach categorises the discursive work of RSMs as a 'framing activity', part of a 'strategic challenge.' Frames are essentially enabling, that is, they facilitate the 'problematic accomplishment' of meaning and significance through the "... weaving, (this) blending, (this) knitting or stitching together of strands of history (...), beliefs or ideology (...), and selected events ..." (Snow and Byrd 2007). The consolidating of a frame of reference makes it possible, Best (2003) explains, for individuals to orient themselves, and translate (strategically) social, political, and historical conditions into orienting meanings: meanings that delineate problems and prescribe specific responses. This interpretation, however, conflates acts of knowing with the organising task of ideology, and relegates the epistemic agency of the radical subject to an explanatory device of sociologists. The radical community's knowledge of the social and political environment is regarded as little more than a coercive construct of movement leaders and political experts.

The social world may be unintelligible and agents' acts incomprehensible if they are inexplicable in some sense as strategic. However, the new struggles in Italy, whether of the late 1950s or mid-1970s, were organised, intelligent, imaginative, and driven by an independent knowledge of their situation. Strategy oriented approaches to explicating the role of radical schemas of thought in politics appear to limit the opportunity for radical theory and practice to inform our sociological account of the radical community. Much of the discursive work of the radical subject that developed and articulated ideas, have become categorised as the 'resources' of collective action. SMT's account of activism builds on the presupposition that social agents are guided by instrumental reasoning, which, deploying the classical notion of rationality, is focused on the best means of achieving a contingent end. This bonds the knowledge practices of the radical community to political activism, and disbars it from epistemology. Strategy-oriented modelling of the dynamics of radical action concentrates on how collective actors do things with the available resources. As such, della Porta asserts, the disruptive, disorderly, and innovative activities of marginalised communities are a means to gain 
voice and achieve visibility through persuasion or coercion, attracting public attention, which, when successful, activates the support of organisations within the political arena (della Porta 2008). As such, the discursive work and documents of the radical community are thought incapable of speech in the rhetorical spaces of the political institution.

However, if we accept radical theory is a factor in the realisation of the radical community, then, equally, we must be mindful of what is at stake in radical thought. Theoretical representations, political organisation, and frames of reference interweave elements of explanation and prescription, analysing the self-activity of the movement while advancing abstract political goals. This 'entanglement of politics and epistemology', as Toscano refers to it in Fanaticism, complicates the separation of prescription and political commitment from explanation (Toscano 2010). This is problematic for SMT, which at certain theoretical junctures dissolves the knowledge of the movement into that of the 'experts'. As previously mentioned, this risks fusing the self-awareness of the radical community with the emblematic statements of the political elite or 'interpreters', and in the Italian situation this theoretical tendency has welded the subjectivity of the movement to caricatures of historical Marxism and a neo-Leninist vanguard. This entitles the elite to speak as the representative of the radical community and facilitates the facile recovery of the latter's knowledge within the frameworks of the relevant interpretive community, promoted ahead of the knowledge practices of the broader radical collective.

Alberto Melucci, renowned for his work in the field of New Social Movement Theory, observes a challenge similar to that witnessed by Toscano. In Challenging Codes Melucci (1996) states that the discursive dimension of social movements contains elements of knowledge, ideology, and integralism, which must be deconstructed if used to theorise the meaning of collective action. Integralism and ideology perform a strategic function, organising the plurality of interests within the movement, rationalising and representing the actions of the social actor. This strategic function overlays the knowledge practices of the radical community, where they struggle against the hegemony of social knowledge inscribed in the discourse of dominant interests (Melucci 1996). Accordingly, the existing order of society and discourses that have that order as their object, have a role in maintaining the intellectual subordination of the radical community. However, as previously argued (removed for blind review), the nature of the radical subject is to disrupt the hegemony of social knowledge. Emancipatory practice breaks from the political and epistemic communities that pacify the radical actor and subordinate it to organisation from above, theoretical intervention, and the statements of political elite. If we are dismissive of this dimension of the radical community and their epistemic agency, falling back upon presumptions of credibility formed around social identity and location, our exposition presents an abstract and deformed subject. 


\section{The radical community and access to knowledge}

Melucci claims that the fundamental conflict in contemporary society is over who has access to knowledge, which is inequitably distributed, and involves a struggle to 'reclaim knowledge', or more accurately, to refuse "the exclusion from knowledge (Melucci 1981)." As mentioned above, this exclusion against which they struggle is explicable as the outcome of rhetorical spaces and the associated presumptions of credibility. Therefore, vital to contemporary movements is access to the epistemic resources deemed necessary to knowledge practices. A similar exclusion has befallen the social documents held in radical community archives at the hand of disciplinary thought and other interpretive communities such as the Italian State and the social movement organisations of the neo-Leninist intellectuals. These entities twice exclude the radical community from the knowledge practices of antagonism. An example is the popular portrayal of the counter-cultural movement as "unable to participate in public assemblies with sensible speeches" (Torealta 1980). Within this rhetorical space, counter-cultural collectives were not granted the rational authority to speak, looked upon as merely noise-makers.

Through my research, I have come to believe that contemplating the nexus of politics and the radical community requires more than its evaluation in terms of political rationality and organisation. Essentially, it involves questions of the hegemony of social knowledge, and requires the recovery of radical thought and deconstructing of organisational analyses that reduce radical practice to strategic abstractions. However, SMT, through traditional schemas of epistemic evaluation and partisan habits of attention, reduces the capacity of the radical community to create new concepts, arguments and questions to the instruments of persuasion and coercion, treated similarly to proselytising ideologies. Subsequently, SMT fails to engage critically with the theory and practice of the radical actor in Italy. Such a failure of engagement is an example of the unfair epistemic discrimination on behalf of mainstream sociology, dismissing the veracity and value of the knowledge practices of radical communities, especially that of the grass-roots participants. This has the consequence of granting SMT rational authority and allows the discipline to monopolise the concepts and explanatory categories of the nexus of politics and the radical community. Further, the disciplinary modelling of the radical actor promotes the abstract thought of movement leaders and their efforts to organise and politicise the radical community, escalating the importance of the political elite and interventionist intellectuals in radical action. This expropriates the wider movement of its knowledge of antagonism, which is significant for at least two reasons. First, as Melucci states, one of the most important functions of the radical community is the legitimising of alternative knowledge practices and modalities of communication. Collective actions, he contends, provide "different ways of addressing things and of imagining them (...), beyond those inscribed in the hegemonic codes of scientific and technological discourse" (Melucci 1996). 
Second, Bologna (1995) argues that initially the creativity of the grass roots movement, consisting of 'thousands of comrades', displayed consciousness and independent knowledge. By participating in Italy's radical social science, the hope of the intellectual was to generate theories attentive to the experiences of the worker. The focus was on opening a relationship with a movement with its own histories of struggle that endowed them with knowledge and the capacity for self-organisation (Cuninghame and Bologna 1995). However, while the original intent of co-research was to record the creativity and innovation of the worker, and to learn from their practice and discourse, in the end the intellectuals would alienate the movement of their knowledge, which they would 'ideologise ex-post' (Cuninghame and Bologna 1995). ${ }^{12}$ The resultant mistake was the reimposition of a discourse upon the radical community rather than a comprehending of their revolutionary form (Bologna 1980). A consequence of this 'failed dialectic' between the movement and the intellectual, noted by Castellano (1980), was the misrepresentation of the actual movement in the frames of leadership. This misrepresentation is compounded when SMT affords the political experts, particularly the Leninists, a voice that resounds beyond their actual position in the radical community, discounting other far left initiatives.

\section{Radical archives and knowledge practices}

What has happened to the discursive materials of the Italian radical community, discounted as epistemic sources by so much sociological thought? This 'surplus' crucially finds a place amongst the Italian community archives, alongside privileged social subjects, research materials, and memory. Accordingly, I promote an alternative approach to archival work favoured by Rancière, who, as Deranty (2010) acknowledges, studied the multiplicity of voices and forms of speech "below the overbearing discourse of organised Marxism." This is testament to Rancière's belief that, contra SMT, the reasoning of those subjects dominated within the existing social order (discounted as speakers and interpreters in certain rhetorical spaces) is the equal of the rationality and logic of the so-called experts and specialists who govern the dialogue on the natural order of society (Rancière 1989). Rancière takes seriously the perspective of the exploited and their capacity to articulate and organise their experience, a theoretical commitment reflected, as Deranty (2012) shows, in his effort to relay 'thought from below'.

The capacity of the radical community for discourse and reason, on display among the social documents held across the Italian radical community archives, questions the reasons for their exclusion from intellectual labour, staking a role in knowledge practices. In the first instance, we should avoid treating 'knowledge from below' as a partial epistemological phenomenon that requires an intellectual intervention or further explication for understanding to occur. We should acknowledge that the radical

12 This review of co-research also forms part of a previous study on radical thought and critical pedagogy in (removed for blind review). 
community can speak about and organise their experience. This is to recognise their epistemic agency, to raise their position in the relevant rhetorical spaces, a position partially justified by the myriad of social documents available in the Italian radical community archives. Therefore, we must be aware the role of the radical community in the presentation of social documents in archival situations, while remaining vigilant to avoid the pitfalls of unfair discrimination, partisan attention, and the aggrandising of certain histories.

Common to all the collections I visited in 2011, is a preservation of memory and knowledge practices that continue to contest exclusion from disciplinary areas of discourse. This is critical, for I contend that it is important to ensure that those twice excluded from the knowledge practices of antagonism in the 1960s and 1970s, do not suffer the same fate at places of research and documentation. Certainly these archives are discriminatory, but we recognise that epistemology is not egalitarian. What is important is that the discrimination is not unfair, and the hope is that instead of excluding certain voices from the area of discourse, the archives help elevate those who are typically stripped of their rational authority.

\section{Conclusion}

In the rush to naturalise the radical subject, giving it a social identity, assigning it a location and task, and designating its time and place in contemporary society, theories of the nexus of politics and the radical community submerge the specificity of marginalised groups beneath identitarian, rationalist, and structuralist aspects of social action. The endeavour to present the radical actor as a stable empirical category of high risk and high cost politics appears motivated by the desire to dignify a theory of radicalisation through its subject, what Bologna (2005) refers to as the 'creation of alibis'. However, this approach is prone to false witness where an ideological hegemony is observed amongst the diversity, innovation, and creativity of the radical community. Such hegemony denies the radical subject rational authority and diminishes its epistemic agency, reducing the vicissitudes of the movement sector to the epiphenomena of political struggle. The outcome is that the prevailing sociological models of the 'movement society', which attempt to organise or politicise the radical community as a political actor, efface the difference and particularity essential to that community. A corollary of this is the underrepresentation of radical thought, and an exclusion of the social documents in place at radical community archives. By limiting who can speak and what can be said in the rhetorical space of sociology, SMT excuses itself, whether deliberately or inadvertently, from engaging with the discursive work of the radical community as epistemic sources.

The creativity and innovation of the Italian radical community of the 1960s and 1970s tried to break from the austere and organised forms of political involvement and traditions of militant anti-fascism. It is the latter, however, that draws the attention of SMT, with such beacons of political violence illuminating the sociological search for 
the politics of the radical subject in western democracy. What could the prevailing sociological accounts of the radical community learn if, instead of focusing on the interventionist intellectuals, Marxism-Leninism, political violence, and the organisational perspective, they were attentive to the historiographical stream of Italian radical thought, the outliers of the movement, counter-sociology, and myriad other intellectual figures presented in the community archives? While the former are important aspects of the movement, they need contextualising within the dynamics of the radicalisation of social movements, and the ongoing interplay to be found there between practice and theory. For instance, while the political elite may pose itself, as Giovannetti (1980) reflects, "as the relatively stable expression of social antagonism, as its memory, as the bearer of social values," and we cannot understand the movement without contemplating their role. Equally, we must realise this group is but one layer.

While intimately entangled with the movement, at times the instrumentalist projects of organising dissent beguiles the theorist and leadership, and in these moments, the theory and practice of the movement and the intellectual come apart. It is amongst these fragments that we may discover the nascence of new knowledges, arguments, concepts, reasons, explanations and the like. The most likely place to uncover the documents of such intellectual labour, I contend, are radical community archives, not among emblematic statements, theoretical interventions, or disciplinary thought. Rancière (2006) tells us, his archival project creates a space where, for example, the workers' words are removed from their usual situation - 'social stuff' - and enter into a dialogue as the equal of philosophical narrative. In such instances, he continues, differentiating between those who have speech and those who have voice, is no longer based on a 'principle of discrimination', where the capability of an individual is tied to their social occupation and location. This is an ideal we should have in mind as we engage with the documents and discursive work of the radical subject. 


\section{References}

Baronian, M.-A., Rosello, M., \& Rancière, J. (2008). Jacques Rancière and indisciplinarity. Art and Research, 2(1).

Best, J. (2003). Social Problems. In L. T. Reynolds \& N. J. Herman-Kinney (Eds.), Handbook of symbolic interactionism. Lanham: AltaMira Press.

Bologna, S. (1980). Tribe of Moles. In S. Lotringer \& C. Marazzi (Eds.), Italy: Autonomia post political politics (Vol. 3). New York: Semiotext(e).

Bologna, S. (2005). Negri's Proletarians and the State: A Critique (E. Emery, Trans.). In T. Murphy, S \& A.-K. Mustapha (Eds.), Resistance in Practice: The philosophy of Antonio Negri. London: Pluto Press.

Casas-Cortés, M. I., Osterweil, M., \& Powell, D. E. (2008). Blurring Boundaries: Recognizing Knowledge-Practices in the Study of Social Movements. Anthropological Quarterly, 81(1), 17-58.

Castellano, L. (1980). Living with geurrilla warfare. In S. Lotringer \& C. Marazzi (Eds.), Italy: Autonomia Post Political Politics (Vol. 3, pp. 296 p.). New York: Semiotext(e).

Castellano, L., Cavallina, A., Cortiana, G., et al. (1996). 'Do You Remember Revolution?' (Trans) Maurizia Boscagli, In Virno, P., and Hardt M., (Eds.) Radical Thought in Italy: A Potential Politics. Minneapolis: University of Minnesota Press

Code, L. (2011). Rhetorical spaces: Essays on gendered locations. New York: Oxford University Press.

Cuninghame, P. (2002) Autonomia: A Movement of Refusal. Social Movements and Social Conflict in Italy in the 1970. Middlesex University

Cuninghame, P., \& Bologna, S. (1995). For an Analysis of Autonomia: An interview with Sergio Bologna. Retrieved from http://libcom.org/library/analysis-of-autonomia-interviewsergio-bologna-patrick-cunninghame

D'Agostino, S. (2013). Archivio Finzi: Il lavoro operaio diverra storia. Zapruder, 32(December).

della Porta, D. (1992). Life-history in the analysis of social movement activists. In M. Diani \& R. Eyerman (Eds.), Studying collective action. London: Sage.

della Porta, D. (1995). Social movements, political violence, and the state: a comparative analysis of Italy and Germany. Cambridge: Cambridge University Press.

della Porta, D. (2008). Research on Social Movements and Political Violence. Qualitative Sociology, 31, 221-230.

Deranty, J.-P. (2010). Logical Revolts. In J.-P. Deranty (Ed.), Jacques Rancière: Key Concepts. Durham: Acumen Publishing.

Deranty, J.-P. (2012). Work in the writings of jacques ranciere. In J.-P. Deranty \& A. Ross (Eds.), Jacques Rancière and the Contemporary Scene: The philosophy of radical equality. London: Continuum.

Deranty, J.-P., \& Ross, A. (Eds.). (2012). Jacques Rancière and the Contemporary Scene: The philosophy of radical equality. London: Continuum.

Diani, M., \& Eyerman, R. (1992). The study of collective action: Introductory remarks. In M. Diani \& R. Eyerman (Eds.), Studying collective action. London: Sage. 
Dotson, K. (2014). Conceptualizing epistemic oppression. Social Epistemology, 28(2), 115-138.

Eyerman, R. (1989). Social movements between history and sociology. Theory and Society, 18, 531-545.

Fricker, M. (2011). Rational authority and social power: Towards a truly social epistemology. In A. Goldman \& D. Whitcomb (Eds.), Social epistemology: essential readings: Oxford University Press.

Fuller, S. (2012). Social epistemology: A quarter-century itinerary. Social epistemology, 26(3-4), 267-283.

Giovannetti, G. (1980). Il movimento e le leggi della guerra. Collegamenti, 8.

Goldman, A. (2011). A guide to social epistemology. In A. Goldman \& D. Whitcomb (Eds.), Social epistemology: essential readings: Oxford University Press.

Goldman, A. I. (2001). Experts: which ones should you trust? Philosophy and Phenomenological Research, 63(1), 85-110.

Howard, M. (2017) A question of knowledge: Radical social movements and self-education." In Means, A., Ford, D.R., and Slater, G.B. (eds). Educational commons in theory and practice: Global pedagogy and politics, Palgrave-Macmillan.

Lotringer, S., \& Marazzi, C. (1980). The Return of Politics. In S. Lotringer \& C. Marazzi (Eds.), Italy: Autonomia post political politics (Vol. 3). New York: Semiotext(e).

McAdam, D. (2004). Revisiting the U.S. Civil Rights Movement: Toward a More Synthetic Understanding of the Origins of Contention. In J. Goodwin \& J. M. Jasper (Eds.), Rethinking social movements : structure, meaning, and emotion. Lanham, Md.: Rowman \& Littlefield Publishers.

McAdam, D., Tarrow, S., \& Tilly, C. (2001). Dynamics of Contention. Cambridge: University of Cambridge Press.

McPhail, C., \& Tucker, C. W. (2003). Collective Behaviour. In L. T. Reynolds \& N. J. HermanKinney (Eds.), Handbook of symbolic interactionism. Lanham: AltaMira Press.

Melucci, A. (1981). Ten Hypotheses for the analysis of new movements. In D. Pinto (Ed.), Contemporary Italian sociology : a reader (1st ed.). Cambridge: Cambridge University Press

Melucci, A. (1996). Challenging codes: collective action in the information age. Cambridge: Cambridge University Press.

Moroni, P. (1994). Origine dei centri sociali autogestiti a Milano. Appunti per una storia possibile. In F. Adinolfie (Ed.), Comunità virtuali. I centri sociali in Italia. Rome: Manifestolibri.

Moss, D. (1989). The Politics of Left-Wing Violence in Italy, 1969-85. London: Macmillan.

Moss, D. (1997). Politics, Violence, Writing: The Rituals of 'Armed Struggle' in Italy. In D. E. Apter (Ed.), The Legitimization of Violence. London: Macmillan.

Portelli, A. (1985). Oral testimony, the law and the making of history: The 'April 7' murder trial. History Workshop, 20(Autumn), 5-35.

Rancière, J. (1989). The nights of labour: the workers dream in nineteenth-century France. Philadelphia: Temple University Press. 
Rancière, J. (1991). The ignorant schoolmaster: five lessons in intellectual emancipation. Stanford: Stanford University Press.

Rancière, J. (2004). The politics of aesthetics: the distribution of the sensible (G. Rockhill, Trans.). London: Continuum.

Rancière, J. (2006). Thinking between disciplines: an aesthetics of knowledge. Parrhesia, 1, $1-12$.

Rancière, J. (2009). Aesthetics and its discontents. Cambridge: Polity Press.

Ross, K. (1991). Translator's Introduction The ignorant schoolmaster: five lessons in intellectual emancipation (pp. xxiii, 148 p.). Stanford: Stanford University Press.

Snow, D. A., \& Byrd, S. C. (2007). Ideology, Framing Processes, and Islamic Terrorist Movements. Mobilization: An International Quarterly Review, 12(1), 119-136.

Stillman, L., \& Johanson, G. (2009). Constructing and sharing memory: Community informatics, identity and empowerment: Cambridge Scholars Publishing.

Tarrow, S. G. (1989). Democracy and disorder: protest and politics in Italy, 1965-1975. New York: Oxford University Press.

Torealta, M. (1980). Painted Politics. In S. Lotringer \& C. Marazzi (Eds.), Italy: Autonomia Post Political Politics (Vol. 3, pp. 296 p.). New York: Semiotext(e).

Toscano, A. (2009). A Plea for Prometheus. Critical Horizons: A Journal of Philosophy and Social Theory, 10(2), 241-256.

Toscano, A. (2010). Fanaticism: On the uses of an idea. London: Verso.

Touraine, A. (2008). An Introduction to the Study of Social Movements. In V. Ruggiero \& N. Montagna (Eds.), Social movements: A Reader. London: Routledge.

Wright, S. (2005). A Party of Autonomy? In T. Murphy, S \& A.-K. Mustapha (Eds.), Resistance in Practice: The philosophy of Antonio Negri. London: Pluto Press.

Wright, S. (forthcoming) The weight of the printed word: Operaismo in text and context. Amsterdam: Brill.

Zwerman, G., Steinhoff, P. G., \& della Porta, D. (2000). Disappearing Social Movements: Clandestinity in the Cycle of New Left Protest in the U.S., Japan, Germany, and Italy. Mobilization: An International Journal, 5(1), 85-104. 